\title{
Internal Efficiency of Public and Private Junior Secondary Schools in Ekiti State
}

\author{
Professor J. B. Ayodele \\ tolayodele@yahoo.co.uk
}

\section{Adeleke Foluso Florence}

ffayanadeleke@yahoo.com

\author{
Doi:10.5901/mjss.2015.v6n5s1p154
}

\begin{abstract}
This study investigated the internal efficiency of private and public secondary schools in Ekiti State from 2005/2006 to 2007/2008 academic session. The objective of the study was to identify the relationship between internal efficiency of Junior Secondary Schools in Ekiti State and variables like class size, school size, teachers' qualification and student-teacher ratio (STR). The ex-post factor research design was used for the study. The sample size consisted of 30 public and 20 private schools in the state selected through purposive and proportional stratified random sampling techniques. The research instrument used to collect data was a validated inventory titled "Data on School Records and Students". True cohort method was used to determine the wastage ratio and consequently the coefficient of efficiency of 30 public and 20 private secondary schools in Ekiti State. T-test and Multiple Regression Statistic were used to test the hypotheses at 0.05 level of significance. It was discovered that private junior secondary schools have higher wastage rates than public secondary schools in Ekiti State. Specifically, the findings showed a higher percentage of dropouts in private junior secondary schools during the period of study. The coefficient of efficiency for public schools was therefore $90 \%$ while it was $73 \%$ in the private secondary schools in Ekiti State. This shows that both public and private secondary schools in Ekiti State were fairly internally efficient. However, public schools were more internally efficient than private schools. In the light of the findings, it was recommended that both private and public schools in Ekiti State should improve in the areas that constituted to high wastage rates, especially in private schools that had higher wastage ratio and work towards a perfect internal efficiency.
\end{abstract}

Keywords: Internal efficiency; Relationship; Student-Teacher Ratio; Cohort; Wastage Ratio; Coefficient of Efficiency.

\section{Introduction}

Education is an instrument which the Federal Government of Nigeria has decided to use to achieve national development. The broad goal of secondary education as contained in the National Policy of Education shall be to prepare the individual for useful living within the society and prepare him for higher education (Federal Republic of Nigeria, 2004). The policy of JSS class as a terminal class provide is an excellent opportunity for Nigeria to confront some of her educational challenges. At the level of Junior Secondary Education, students were to be exposed to technical and vocational education such that on completion, those not academically inclined could pursue specialization in technical colleges. This study of internal efficiency of junior secondary school is to investigate factors that threaten its effectiveness in a cycle of three years.

Bisi, Kofoworola and Adegunle (2010) reported that the government had reviewed the 6-3-3-4 system and concluded that it has failed to meet the aspiration of its promoters as well as inability to adequately respond to many challenges facing education in Nigeria. Olubor (2004) opined that education as a dynamic system requires certain inputs from time to time to carry out the curricular activities designed for the achievement of the system's goals. The inputs included teachers, both in quality and quantity, students, funds, materials and equipment. Adigun (1999) affirmed that the benefits have been met. Unfortunately, not all students that enrolled for the Junior Secondary Education enjoyed the benefit of completing their JSS3 education. Many complete at very high cost in terms of financial and time implications when one weighs the time spent for this level of education by each student in terms of student-years.

Wastage in education manifests when resources given to education are not utilized to produce the output at the stipulated time and education system of the school can be considered less efficient. Public schools are owned, managed and financed by the government. The government spend large amount of money on education including overhead cost and grants to secondary schools. Meanwhile, private schools are schools owned and managed by individual proprietors 
or proprietresses for the purpose of making profits, though licensed by the government. Private schools are expected to be more efficient because they have the privilege of screening pupils for admission and admit only the able pupils. More so, private school students pay fees, their sponsors pay more attention to the education of their wards. They equally organize extra lessons for their children/wards compared to students of public schools. Ayeni (2005) opined that private institutions evolve for reasons of provision of services and the maximization of profit.

The internal efficiency of any school depends upon the way it is managed, planned and administered. According to Ajayi and Ayodele (2001), planning is a process of deciding in advance what to do such that programmes are executed at minimum risk of failure. The researcher observed that wastage may have been attributed to inadequacies in school production variables. The variables include the learning environment, student-teacher ratio, teachers' motivation, school organizational climate, teachers' quality and quantity. These are independent variables that the academic performance of a student depends upon while in school. Common observation shows that public schools especially junior secondary schools, lack adequate chairs/desks and classrooms. The school learning environment is disgusting and hostile resulting into high cases of school dropouts. Another factor that could influence efficiency includes high enrolment and increased class size. Undoubtedly, these factors have impairing tendencies on internal efficiency.

It remains a fact that adequacies in school production variables facilitate internal efficiency. However, the arising question is: do these school production variables still affect internal efficiency of public and private secondary schools in Ekiti State?

\subsection{Statement of the Problem}

The wastage problem resulting from class repetition and dropout calls for a study, with the view of ascertaining the internal efficiency of public and private Junior Secondary Schools in Ekiti State. It seems that many students tend to go through the school system without making the desired progress. Many students spend extra years in school, thereby constituting wastage. The researcher observed that cases of repetition and dropout in public secondary schools in the state seems to be more rampart than the case of private secondary schools and this might not have been unconnected with certain school related factors such as class size, school size, teachers' qualification and student-teacher ratio.

\subsection{Purpose of Study}

The purpose of this study is to examine the internal efficiency of public and private secondary schools in Ekiti State, Nigeria. The study ascertained whether there is any relationship between the school related variables (such as class size, school size teacher's qualification and student-teacher ratio) and the internal efficiency. The study will also ascertain which is more internally efficient between a public and a private junior secondary school system in Ekiti State.

\subsection{Research Questions}

The following research questions have been raised:

- What is the wastage rate in public and private junior secondary schools in Ekiti State?

- To what extent are public and private junior secondary schools internally efficient?

- Do school related factors such as class size, school size teacher's qualification and student-teacher ratio make significant contribution to internal efficiency?

\subsection{Research Hypotheses}

The following hypotheses have been formulated in the study:

- There is no significant difference between the internal efficiency of private and public secondary schools in Ekiti State

- School related factors such as class size, school size teacher's qualification and student-teacher ratio (STR) do not make any significant contribution to the internal efficiency of public and private junior secondary schools in Ekiti State. 


\section{Research Method}

The research design adopted for this study was descriptive adoption of the ex-post factor type. The study population consists of one hundred and sixty seven (167) public junior secondary schools and one hundred and fourteen (114) private junior secondary schools in Ekiti State. Thirty (30) public and twenty (20) private Junior Secondary school teachers were respectively sampled using purposive and proportional stratified random sampling techniques. A validated inventory titled "data on school records and students" was used to collect data for the study. The data collected were analyzed using descriptive statistics (frequency count and percentages). T-test and multiple regressions were used to test the hypotheses at 0.05 level of significance.

\section{Results}

\subsection{Research Question 1:}

What is the wastage rate in public and private junior secondary schools in Ekiti State?

Table 1: The wastage rate in public and private secondary schools

\begin{tabular}{|l|c|c|c|c|c|c|}
\hline & \multicolumn{3}{|c|}{ PUBLIC } & \multicolumn{3}{c|}{ PRIVATE } \\
\hline Session & Repetition rates & Dropout rates & Wastage rates & Repetition rates & Dropout rates & Wastage rates \\
\hline $2005 / 06$ & 6.9 & 1.27 & 8.17 & 6.8 & 8.7 & 15.5 \\
\hline $2006 / 07$ & 3.73 & 2.45 & 5.94 & 5.94 & 11.33 & 17.27 \\
\hline $2007 / 08$ & 3.92 & 2.48 & 7.79 & 7.79 & 8.72 & 16.51 \\
\hline $2008 / 09$ & 4.99 & 14.96 & 19.95 & 9.52 & 19.05 & 28.57 \\
\hline
\end{tabular}

NB: Figures are in percentage.

Table 1 shows the wastage rates in both public and private Junior Secondary schools in Ekiti State. In 2005/2006 acaddemic session, the wastage rates were $8.17 \%$ and $15.5 \%$ in public and private schools respectively. It was $6.18 \%$ and $17.27 \%$ respectively in Public and Private Schools for the year 2006/2007. In 2007/2008 (the expected year of graduation), the wastage rates were $6.32 \%$ and $16.51 \%$ in public and private junior secondary schools respectively. Some students could not meet up at the end of the ideal three years cycle between 2005/2006 and 2007/2008 academic sessions. The wastage rates in 2008/2009 were $19.95 \%$ and $28.57 \%$ in public and private junior secondary schools, respectively.

\subsection{Research Question 2:}

To what extent are the public and private junior secondary schools internally efficient?

In order to determine the internal efficiency, the wastage ratio was computed. The reciprocal of the wastage ratio was also computed to determine the coefficient of efficiency.

Wastage ratio was determined as follows:

Wastage Ratio = Actual Input - Output Ratio

Ideal Input - Output Ratio

Table 2: The internal efficiency of selected private and public secondary schools in Ekiti State.

\begin{tabular}{|c|c|c|c|c|c|}
\hline Type of School & Input (Student- years) & Output (Completer) & Actual (Input/output) & Wastage Ratio & Coefficient of Efficiency \\
\hline Private & 2288 & 558 & 4.10 & 1.37 & $73 \%$ \\
\hline Public & 13,327 & 4008 & 3.33 & 1.11 & $90 \%$ \\
\hline
\end{tabular}

From the flow chart of the true cohort constructed, Table 2 revealed that one successive completer in private school used 4.10 student-years to complete while it took 3.33 student years to complete in public junior secondary school education in Ekiti State during the period of study. This table further shows that the coefficient of efficiency of public and private junior secondary schools were $90 \%$ and $73 \%$ respectively. This implies that public junior secondary schools were more internally efficient than private junior secondary schools during the period of study. 


\subsection{Testing of Hypotheses}

Hypotheses 1: There is no significant difference between the internal efficiency of private and public secondary schools in Ekiti State.

Table 3: T-test analysis difference in the internal efficiency between private and public secondary schools in Ekiti State.

\begin{tabular}{|l|c|c|c|c|c|c|c|}
\hline School Type & N & Mean & SD & T-CAL & DF & T-TABLE & Remark \\
\hline Private & 20 & 42.42 & 0.41 & \multirow{2}{*}{3.41} & 142 & +1.96 & \multirow{2}{*}{ Sign } \\
\hline Public & 30 & 97.62 & 1.57 & & & & \\
\hline
\end{tabular}

Table 4 shows that t-value calculated (3.41) was greater than the critical table value (1.96) at 0.05 level of significance. Therefore, the null hypothesis was rejected. There is therefore significant difference in internal efficiency between the private and public junior secondary schools in Ekiti State.

Hypotheses 2: School related factors such as class size, school size, teachers' qualification, and student-teacher ratio do not make any significant contribution to the internal efficiency of Junior Secondary Schools in Ekiti State.

Table 4: Relative contribution of each selected school factors to the internal efficiency in private Junior Secondary Schools in Ekiti State.

\begin{tabular}{|l|c|c|c|c|c|c|}
\hline Selected School Variables & Code & Contribution of each variable & Standard Error & T-cal & Sig.t (p-value) & Remark \\
\hline Class Size & X1 & 0.001249 & 0.153 & 0.166 & 0.003 & Sign \\
\hline School Size & X2 & 0.001447 & 0.131 & 0.817 & 0.003 & Sign \\
\hline Teachers' Qualification & X3 & 0.0797 & 0.384 & 0.415 & 0.925 & Not Sign \\
\hline Student- Teacher Ratio & X4 & 0.09292 & 0.133 & 1.212 & 0.002 & Sign \\
\hline
\end{tabular}

Table 4 shows p-value of $0.003,0.003$ and 0.002 for class size, school size and student-teacher ratio, respectively less than t-calculated at 0.005 alpha level which means they are significant to internal efficiency. Only teachers' qualification shows a p-value of 0.925 that was greater than t-calculated. This implies that teachers' qualification made no significant contribution to the internal efficiency of private Junior Secondary Schools in Ekiti State.

Table 5: Relative contribution of each selected school factors to the internal efficiency in public Junior Secondary Schools in Ekiti State.

\begin{tabular}{|l|c|c|c|c|c|c|}
\hline Selected School Variables & Code & Contribution of each variable & Standard Error & T-cal & Sig.t (p-value) & Remark \\
\hline Class Size & X1 & 0.001647 & 0.131 & 0.166 & 0.002 & Sign \\
\hline School Size & X2 & 0.001447 & 0.131 & 0.817 & 0.003 & Sign \\
\hline Teachers' Qualification & X3 & -0.0797 & -0.362 & 3.219 & 0.002 & Sign \\
\hline Student- Teacher Ratio & X4 & 0.09292 & 0.138 & 1.029 & 0.002 & Sign \\
\hline
\end{tabular}

Table 5 shows the various contribution of the independent variable to the internal efficiency of public junior secondary schools in Ekiti State at 0.05 alpha levels. The p-values 0.002, 0.003, 0.002, 0.002 for class size, school size, teachers' qualification and student-teacher ratio, respectively were less than T-calculated. This shows that there was significant contibution of the variables to the internal efficiency of public junior secondary schools.

\section{Discussions}

The findings from this study showed that private schools have higher wastage rates throughout the period of study. This may be attributed to the fact that private schools do not encourage automatic promotion. However, findings showed a high percentage of dropouts in private Junior Secondary Schools. This may be connected to the high tuition fees in private schools which may be prompt some poor parents to withdraw their children from such schools. It was shown from the study that each selected school-related factors had significant contribution to the internal efficiency except teachers' qualification in private schools. This might be as a result of less qualified teachers employed in private secondary schools used during the period of study. These would have affected the quality of teaching. Farent (1984) and Ukeje (1966). A student completer in the public secondary schppl spent 3.33 student-year while it was 4.10 student-year in the private 
school. The wastage ratio calculated was 1.11 and 1.37 in public and private Junior Secondary Schools respectively. According to Ayodele (2005), a wastage ratio of 1 (which is not achieved in reality) shows a perfect internal efficiency. The nearer the wastage ratio to 1 , the more efficient the system; in contrast, the farther the less. From observation, wastage ratios of 1.11 and 1.37 which are above unit, shows a fairly internal efficiency for secondary schools in a developing country. The coefficient of efficiency for public school was $90 \%$ and $73 \%$ for private school, which are above average. By implication, both public and private Junior Secondary Schools in Ekiti State were fairly internally efficient throughout the period under study i.e.2005/2006 to 2007/2008 academic sessions. Public schools were however more internally efficient than private schools during the period of study due to lesser class repetition and lower dropout rates.

\section{Conclusion and Recommendation}

The selected school- related factors contributed significantly to the internal efficiency of public and private Junior Secondary Schools in the state. The element of wastage rates which appeared in forms of repetition and dropout in the two types of school were minimal. This shows that Ekiti State public and private Junior Secondary Schools were fairly internally efficient during the period of study. However, public Junior Secondary School was more internally efficient than the private counterpart in Ekiti State during the period of study.

Considering the implication of these findings for resource utilization, the following recommendations are considered necessary. Private schools in Ekiti State should address issues causing wastages and adhere strictly to the requirement of the National Policy on Education, most especially in the area of teachers' qualification that requires N.C.E. as the minimum qualification of a teacher in the secondary schools. There is need to employ more qualified teachers to increase academic performance and reduce the rate of repetition and dropouts. In addition, parents should stop having negative perception about the system of operation in public secondary schools in Ekiti State.

\section{References}

Adigun, J.T. (1999) Wastage Factors in Akure Local Government Area Secondary Schools, Ondo State; Journal of Institute of Education, Ondo State University, Ado- Ekiti.

Ajayi, I.A. \& Ayodele J.B. (2001) Introduction to Educational Planning Administration and Supervision; YPPS Publishers, Lagos.

Ayeni, A.O. (2005) Education as an Investment; Journal of Contemporary Issues in Education; Faculty of Education, University of AdoEkiti, Nigeria.

Ayodele, J.B. (2005) Fundamentals of Systems Analysis in Education; Bolabay Publishers, Lagos.

Bisi O., Kofoworola B.O. \& Adegunle O. (2010, October 28) Stakeholders fault 'hurried' plans to dump 6-3-3-4 system; The Nations Newspaper, Page 21

Federal Republic of Nigeria (2004) National Policy of Education.

Olubo, R.O. (2004) A Comparative Analysis of the Internal Efficiency of Public Junior Secondary Education of Two Selected States in Nigeria; Journal of Educational Foundations and Management, University of Ado- Ekiti, Nigeria. 